\title{
Implementasi Data Mining Menentukan Game Android Paling Diminati Dengan Algoritma Apriori
}

\author{
Yulianti $^{1}$, Dwi Yuni Utami ${ }^{2}$, Noer Hikmah ${ }^{3}$ \\ ${ }^{1}$ Program Pascasarjana Magister Ilmu Komputer STMIK Nusa Mandiri \\ Jl. Kramat No.18 Jakarta Pusat \\ Yuleeseunggi@gmail.com
}

${ }^{2}$ Program Studi Sistem Informasi Universitas Bina Sarana Informatika

J1. Kamal Raya No.18 RingRoad Barat, Cengkareng, Jakarta Barat

Dwi.dyu@bsi.ac.id

${ }^{3}$ Program Studi Sistem Informasi Universitas Bina Sarana Informatika

J1. Kamal Raya No.18 RingRoad Barat, Cengkareng, Jakarta Barat

Noer.nhh@bsi.ac.id

\begin{abstract}
Cara Sitasi: Yulianti, Utami, D. Y., \& Hikmah, N. (2019, Maret). Implementasi Data Mining Menentukan Game Android Paling Diminati Dengan Algoritma Apriori. (S. Dalis, Ed.) Paradigma - Jurnal Komputer dan Informatika, 21(1), 29-34. doi:10.31294/p.v21i1.4941
\end{abstract}

\begin{abstract}
Game play at this time is greatly increased among children, teenagers and Parents . various types of games continue to emerge and steal the hearts of enthusiasts. he role of the game quite effective to eliminate saturation, fatigue, sadness, or just want to fill the free time, From starting paid games to free games. To meet The desire of gamers needs to be made an information So that fans can find out. A priori algorithm includes the type of association rules in Mining data. One stage of association analysis, which attracts many researchers to produce an efficient algorithm is the analysis of high frequency patterns (frequent pattern mining). Important or not a buffer association that is known by two benchmarks, namely: support and confidence. Support (support value) presents a combination of items in the database, while confidence (recognition capacity) is a strong correlation between items and a priori algorithm association rules can help determine specialization in a class or group. It can be concluded that the algorithm can facilitate the researcher apriosi to produce output that is measured accurately with the value of the value that has been set. The game support support value is 50\%, and the results of the study can produce $80 \%$ confidence value for game Shadowrun (Dragonfall) dah Knight of pen \& paper 2 , while for game women the support value is 50\% and the results of the research can be 66,7\% for game Candy Crush Saga and other games in demand. From these data it is stated that more men like game-andwoman games.
\end{abstract}

Keywords: specialization, game type, priori algorithmi

\section{PENDAHULUAN}

Game (permainan) secara umum adalah sebuah aktivitas rekreasi dengan tujuan bersenang-senang, mengisi waktu luang, atau berolahraga ringan. Permainan biasanya dilakukan sendiri atau bersamasama (Wardhani \& Yaqin, 2013). Banyaknya persaingan dalam game yang di tawarkan dihandphone android, khususnya game yang banyak dimainkan dikalangan anak-anak, remaja, maupun orangtua.

Saat ini anak-anak memiliki porsi yang cukup besar sebagai pengguna teknologi digital dan diprediksikan akan meningkat secara signifikan pada tahun-tahun mendatang (Delima, Arianti, \& Pramudyawardani, 2015). Begitu banyak jenis game yang terdapat diaplikasi playstore membuat game terbagi dalam beberapa jenis permainan yang lebih dikenal dengan istilah genre. Genre game bisa terdiri dari sebuah genre saja atau bisa merupakan gabungan dari dua atau lebih genre" (Irwandi, Erlansari, \& Effendi, 2016) dalam (Putra \& Utami, 2018).

Pandangan bahwa saat ini game adalah kebutuhan bagi semua kalangan, adalah tantangan tersendiri untuk para pengembang game untuk membuat game yang unik dan berkualitas agar dapat diterima oleh para calon pengguna game tersebut baik untuk 
keperluan hiburan maupun keperluan dalam menghasilkan uang. Hal inilah yang dijadikan peneliti sebagai dasar pengolahan data mining pada aplikasi game karyawan dan karyawati di PT. XYZ. Berdasarkan kuisioner yang peneliti ambil dapat mengetahui game apa saja yang paling banyak di pakai di gemari karyawan dan karyawati di PT. XYZ. dan berdasarkan survei peneliti di web google mencari game apa saja yang menjadi pepuler dan yang terbanyak di gemari di Indonesia.

\section{Rumusan Masalah}

Adapun rumusan masalah yang akan diambil adalah

Bagaimana peneliti menerapkan algoritma apriori untuk mengetahui game mana saja yang paling di minati atau yang paling banyak di mainkan karyawan dan karyawati di PT. XYZ

\section{Tujuan dan Manfaat Penelitian}

Tujuan dari dilakukannya penelitian ini adalah: dapat mengetahui game apa saja yang paling diminati. Adapun mafaat penelitian ini adalah : Untuk mengetahui game apa saja yang banyak di minati dan di mainkan oleh karyawan dan karyawati PT. XYZ.

\section{Implementasi}

Implementasi adalah bermuara pada aktifitas, tindakan, atau adanya mekanisme suatu sistem. Implementasi bukan sekedar hanya aktifitas, tetapi suatu kegiatan yang terencana dan untuk mencapai tujuan kegiatan.

\section{Data Mining}

Menurut Berry dalam (Mabrur \& Lubis, 2012) Data mining adalah proses menganalisa data dari perspektif yang berbeda dan menyimpulkannya menjadi informasi-informasi penting yang dapat dipakai untuk meningkatkan keuntungan, memperkecil biaya pengeluaran, atau bahkan keduanya. Secara teknis, data mining dapat disebut sebagai proses untuk menemukan korelasi atau pola dari ratusan atau ribuan field dari sebuah relasional database yang besar.

Menurut Larose dalam (Gunadi \& Sensuse, 2012) Data mining dibagi menjadi beberapa kelompok berdasarkan tugas/pekerjaan yang dapat dilakukan, yaitu :

a. Deskripsi Terkadang peneliti dan analisis secara sederhana ingin mencoba mencari cara untuk menggambarkan pola dan kecenderungan yang terdapat dalam data. Deskripsi dari pola kecenderungan sering memberikan kemungkinan penjelasan untuk suatu pola atau kecenderungan.

b. Estimasi Estimasi hampir sama dengan klasifikasi, kecuali variabel target estimasi lebih ke arah numerik dari pada ke arah kategori. Model dibangun menggunakan baris data (record) lengkap yang menyediakan nilai dari variabel target sebagai nilai prediksi. Selanjutnya, pada peninjauan berikutnya estimasi nilai dari variabel target dibuat berdasarkan nilai variabel prediksi.

c. Prediksi Prediksi hampir sama dengan klasifikasi dan estimasi, kecuali bahwa dalam prediksi nilai dari hasil akan ada di masa mendatang. Beberapa metode dan teknik yang digunakan dalam klasifikasi dan estimasi dapat pula digunakan (untuk keadaan yang tepat) untuk prediksi.

d. Klasifikasi Dalam klasifikasi, terdapat target variabel kategori. Sebagai contoh, penggolongan pendapatan dapat dipisahkan dalam tiga kategori, yaitu pendapatan tinggi, pendapatan sedang, dan pendapatan rendah.

e. Pengklasteran (Clusterring) Pengklasteran merupakan pengelompokan record, pengamatan, atau memperhatikan dan membentuk kelas obyek-obyek yang memiliki kemiripan. Klaster adalah kumpulan record yang memiliki kemiripan satu dengan yang lainnya dan memiliki ketidakmiripan record dalam klaster yang lain. Berbeda dengan klasifikasi, pada pengklasteran tidak ada variabel target. Pengklasteran tidak melakukan klasifikasi, mengestimasi, atau memprediksi nilai dari variabel target, akan tetapi, algoritma pengklasteran mencoba untuk melakukan pembagian terhadap keseluruhan data menjadi kelompok-kelompok yang memiliki kemiripan (homogen), yang mana kemiripan record dalam satu kelompok akan bernilai maksimal, sedangkan kemiripan dengan record dalam kelompok lain akan bernilai minimal.

f. Asosiasi Tugas asosiasi dalam data mining adalah untuk menemukan atribut yang muncul dalam satu waktu. Salah satu implementasi dari asosiasi adalah market basket analysis atau analisis keranjang belanja.

\footnotetext{
Algoritma Apriori

Algoritma apriori termasuk jenis aturan asosiasi pada data mining. Aturan yang menyatakan asosiasi antara beberapa atribut yang disebut affinity analysis atau market basket analysis. Analisis asosisasi atau association rule mining adalah teknik data mining untuk menemukan aturan suatu kombinasi item.

Implementasi Data Mining Menentukan Game Android....
} 
Salah satu tahap analisis asosiasi yang menarik banyak perhatian peneliti untuk menghasilkan algoritma yang efesien adalah analisis pola frekuensi tinggi.. Penting tidaknya suatu asosiasi dapat diketahui dengan dua tolak ukur yaitu : support dan confidence. Support (nilai penunjang) adalah presentase kombinasi item tersebut dalam database, sedangkan confidence (nilai kepastian) adalah kuatnya hubungan antaritem dalam aturan asosiasi.

\section{Analisa Pola Frekuensi Tinggi dengan Algoritma Apriori}

Tahap ini mencari kombinasi item yang memenuhi syarat minimum dari nilai support dalam basis data. Nilai support sebuah item diperoleh dengan menggunakan rumus berikut :

Support $(\mathrm{A})=\frac{\text { jumlah transaksi mengandung } A}{\text { total transaksi }} * 100 \ldots \ldots(1)$

Sementara, nilai support dari 2 item diperoleh dengan menggunakan rumus berikut :

Support $(\mathrm{A}, \mathrm{B})=\mathrm{P}(\mathrm{A} \cap \mathrm{B})$

Support $=\frac{\sum \text { transaksi mengandung } A \text { dan } B}{\Sigma \text { transaksi }} * 100 \%$

Frequent itemset menunjukan itemset yang memiliki frekuensi kemunculan lebih dari nilai minimum yang ditentukan (Ф). misalkan (Ф)= 2 maka semua itemset yang frekuensi kemunculannya lebih dari atau sama dengan 2 kali disebut frequent. Himpunan dari frequent kitemset dilambangkan dengan Fk.

\section{Pembentukan Aturan Asosiasi}

Setelah semua pola frekuensi tinggi ditemukan, barulah di cari aturan asosiasi yang memenuhi syarat minimum untuk confidence dengan menghitung confidence aturan asosiatif. Nilai confidence dari aturan diperoleh dengan rumus berikut :

Confidence $=\frac{\Sigma \text { transaksi mengandung A dan } B}{\Sigma \text { transaksi mengandung } A} * 100$

Untuk menentukan aturan asosiasi yang akan dipilih maka harus diurutkan berdasarkan Support $x$ Confidence. Aturan diambil sebanyak $\mathrm{n}$ aturan memiliki hasil terbesar.

\section{BAHAN DAN METODE}

Bahan Masalah diambil pada PT. XYZ yaitu mengenai Data Game yang paling banyak diminati dan dimainkan oleh karyawan dan karyawati yang diambil melalui kuisioner yang bagikan digroup whatsapp. Oleh sebab itu PT. XYZ memerlukan sistem untuk mengolah data yang dapat menghasilkan data game yang paling banyak dimainkan tersebut dan dapat menjadi acuan untuk mengetahui game apa saja yang paling banyak diminati dan dimainkan.

Daftar game yang Dibuat Kuisioner.

Berikut ini adalah daftar game yang penulis ambil sampel atau contoh dari hasil pencarian daftar nama game yang paling banyak diminati atau yang paling banyak di mainkan melalui google.com. dapat dilihat pada tabel dibawah ini game paling banyak dimainkan oleh masyarakat di indonesia pada umumnya.

Tabel 1 : Daftar game Karyawan Pria

\begin{tabular}{|c|c|}
\hline NO & Nama Game \\
\hline 1. & Shadowrun (Dragonfall) \\
\hline 2. & Knight of pen \& paper 2 \\
\hline 3. & Inflation RPG \\
\hline 4. & Chaos Rings III \\
\hline 5. & Lainnya \\
\hline
\end{tabular}

Sumber: diambil dari data game yang paling banyak diminati oleh masyarakat se Indonesia di detikgadget.com

Tabel 2 : Daftar game Karyawan Wanita

\begin{tabular}{|c|c|}
\hline NO & Nama Game \\
\hline 1. & Candy Crush Saga \\
\hline 2. & The Sims \\
\hline 3. & Hay Day \\
\hline 4. & Looklet \\
\hline 5. & Lainnya \\
\hline
\end{tabular}

Sumber: diambil dari data game yang paling banyak diminati oleh masyarakat se Indonesia di teknonetwork.com

\section{HASIL DAN PEMBAHASAN}

Algoritma apriori bertujuan untuk menemukan semua aturan apriori yang memenuhi syarat minimum support (nilai penunjang), yaitu kombinasi tiap item dalam database dan syarat minimum confidence (nilai kepastian), yaitu kuatnya hubungan antara item dalam aturan asosiasi.

\section{Pola Pengambilan Kuisioner Pada PT. XYZ}

Berdasarkan pengambilan kuisioner karyawan dan karyawati PT. XYZ melalui pesan yang penulis kirimkan melalui group WhatsApp (WA) tersebut dapat diakumulasikan. Akumulasi kuisioner dapat dilihat dari hasil kuisioner semua karyawan dan karyawati, dapat dilihat dalam tabel dibawah ini :

Tabel 3 : Pola Kuisioner Peminatan Game Karyawan Pria

\begin{tabular}{|c|c|}
\hline NO & Itemset \\
\hline 1. & $\begin{array}{c}\text { Shadowrun (Dragonfall), Knight of } \\
\text { pen \& paper 2 }\end{array}$ \\
\hline
\end{tabular}




\begin{tabular}{|c|c|}
\hline 2. & $\begin{array}{c}\text { Shadowrun (Dragonfall), Inflation } \\
\text { RPG }\end{array}$ \\
\hline 3. & Knight of pen, Lainnya \\
\hline
\end{tabular}

Sumber: diambil dari hasil perhitungan kuesioner yang penulis berikan kepada seluruh karyawan yang ada di PT. XYZ.

Tabel 4 : Pola Kuisioner Peminatan Game Karyawan Wanita

\begin{tabular}{|c|c|}
\hline NO & Itemset \\
\hline 1. & Candy Crush Saga, Hay Day \\
\hline 2. & Candy Crush Saga, Lainnya \\
\hline
\end{tabular}

Sumber: diambil dari hasil perhitungan kuesioner yang penulis berikan kepada seluruh karyawan yang ada di PT. XYZ.

\section{a. Pembentukan Itemset}

Berikut ini adalah penyelesaian dengan contoh kasus berdasarkan data yang sudah disediakan pada tabel di atas. Proses pembentukan atau disebut dengan 1 itemset dengan jumlah minimum support $=30 \%$ Dengan rumus sebagai berikut :

Support $(\mathrm{A})=\frac{\Sigma \text { kuisioner } A}{\Sigma \text { kuisioner }} * 100$

Berikut hasil perhitungan nilai support yang penulis hitung berdasarkan dari hasil kuisioner yang penulis berikan kepada semua karyawan dan karyawati yang ada di PT. XYZ.

Perhitungan nilai support game karyawan pria sebagai berikut :

Support $\left(\right.$ Shadowrun $($ Dragonfall $)=\frac{20}{36} * 100 \%=55,55 \%$ Support (Knight of pen \& paper 2$)=\frac{7}{36} * 100 \%=19,44 \%$ Support (Inflation RPG) $=\frac{3}{36} * 100 \%=8,33 \%$

Support (Chaos Rings III) $=\frac{5}{36} * 100 \%=13,88 \%$

Support $($ Lainnya $)=\frac{8}{36} * 100 \%=22,22 \%$

Tabel 5 : Support Dari Tiap item game Pria

\begin{tabular}{|c|c|}
\hline Itemset & Support \\
\hline Shadowrun (Dragonfall) & $55,55 \%$ \\
\hline Knight of pen \& paper 2 & $19,44 \%$ \\
\hline Inflation RPG & $8,33 \%$ \\
\hline Chaos Rings III & $13,88 \%$ \\
\hline Lainnya & $22,22 \%$ \\
\hline
\end{tabular}

Sumber: diambil dari hasil perhitungan keusioner yang penulis berikan kepada semua karyawan dan karyawati yang ada di PT XYZ.

Perhitungan game karyawan wanita sebagai berikut :

Support $\left(\right.$ Candy Crush Saga) $=\frac{15}{24} * 100 \%=62,5 \%$

Supprt (The Sims) $=\frac{4}{24} * 100 \%=16,66 \%$

Support (Hay Day) $=\frac{3}{24} * 100 \%=12,5 \%$
Support $($ Looklet $)=\frac{3}{24} * 100 \%=12,5 \%$
Support $($ Lainnya $)=\frac{1}{24} * 100 \%=4,16 \%$

Support $($ Lainnya $)=\frac{1}{24} * 100 \%=4,16 \%$

Tabel 6 : Support Dari Tiap item game Wanita

\begin{tabular}{|c|c|}
\hline Itemset & Support \\
\hline Candy Crush Saga & $62,5 \%$ \\
\hline The Sims & $16,66 \%$ \\
\hline Hay Day & $12,5 \%$ \\
\hline Looklet & $12,5 \%$ \\
\hline Lainnya & $4,16 \%$ \\
\hline
\end{tabular}

Sumber: diambil dari hasil perhitungan keusioner yang penulis berikan kepada semua karyawan dan karyawati yang ada di PT. XYZ.

b. Kombinasi 2 itemsset Proses atau disebut dengan 2 itemset dengan jumlah minimum support $=50 \%$ Dapat diselesaikan dengan rumus berikut support $(\mathrm{A}, \mathrm{B})=\mathrm{P}(\mathrm{A}$ n $\mathrm{B})$

Support $(\mathrm{A}, \mathrm{B})=\frac{\sum \text { kuisioner Mengandung } \mathrm{A} \text { dan } B}{\Sigma \text { kuisioner }} * 100 \%$

Berikut hasil perhitungan nilai kombinasi 2 itemset yang penulis hitung berdasarkan dari hasil kuisioner yang penulis berikan kepada semua karyawan dan karyawati yang ada di PT. XYZ.

Perhitungan nilai 2 itemset game pria sebagai berikut :

Confident (Shadowrun (Dragonfall), Knight of pen $\&$ paper 2$)=\frac{20+7}{27} * 100 \%=80 \%$

Confident (Shadowrun (Dragonfall), Lainnya) = $\frac{20+8}{28} * 100 \%=20 \%$

Tabel 7 : Calon 2-Itemset game Karyawan Pria

\begin{tabular}{|c|c|c|}
\hline Itemset & Jumlah & Support \\
\hline $\begin{array}{c}\text { Shadowrun } \\
\text { (Dragonfall), } \\
\text { Knight of pen \& } \\
\text { paper }\end{array}$ & 4 & $80 \%$ \\
\hline $\begin{array}{c}\text { Shadowrun } \\
\text { (Dragonfall), } \\
\text { Lainnya }\end{array}$ & 2 & $40 \%$ \\
\hline
\end{tabular}

Sumber: diambil dari hasil perhitungan kuisioner yang penulis berikan kepada semua karyawan dan karyawati PT. XYZ.

Perhitungan nilai 2 itemset game wanita sebagai berikut :

Confident (Candy Crush Saga, The Sims) $=\frac{15}{24} *$ $100 \%=62,5 \%$

Confident (Candy Crush Saga, Lainnya) $=\frac{1}{24} *$ $100 \%=4,16 \%$ 
Tabel 8 : Calon 2-Itemset game Wanita

\begin{tabular}{|c|c|c|}
\hline Itemset & Jumlah & Support \\
\hline $\begin{array}{c}\text { Candy Crush Saga, } \\
\text { The Sims }\end{array}$ & 15 & $62,5 \%$ \\
\hline $\begin{array}{c}\text { Candy Crush Saga, } \\
\text { Lainnya }\end{array}$ & 1 & $4,16 \%$ \\
\hline
\end{tabular}

Sumber: diambil dari hasil perhitungan kuisioner yang penulis berikan kepada semua karyawan dan karyawati PT. XYZ.

Penulis hanya menghitung sampai 2 itemset saja, karena kombinasi 3 itemset tidak ada yang memenuhi syarat minimal support, maka 2 kombinasi saja yang penulis buat dan yang memenuhi untuk pembentukan asosiasi.

Pembentukan Aturan Asosiasi Setelah semua pola frekuensi tinggi ditemukan, barulah dicari aturan asosiasi yang memenuhi syarat minimum untuk confidence dengan menghitung confidence aturan asosiatif A->B. Minimal Confidence $=60 \%$ Nilai Confidence dari aturan A->B diperoleh dengan rumus berikut :

Confident $=\frac{\sum \text { kuisioner Mengandung A dan } B}{\Sigma \text { transaksi mengandung } A} * 100 \%$......(6)

Dari kombinasi dari 2 itemset yang telah ditemukan, dapat dilihat besarnya nilai support, dan confidence dari calon aturan asosiasi seperti tampak pada tabel dibawah ini :

Tabel 9 : Aturan Asosiasi game Pria

\begin{tabular}{|c|c|c|}
\hline Aturan & Support & Confident \\
\hline $\begin{array}{l}\text { Jika memainkan } \\
\text { game Shadowrun } \\
\text { (Dragonfall), } \\
\text { maka memainkan } \\
\text { game Knight of } \\
\text { pen \& paper }\end{array}$ & $4 / 5$ & $80 \%$ \\
\hline $\begin{array}{l}\text { Jika memainkan } \\
\text { game Shadowrun } \\
\text { (Dragonfall), } \\
\text { maka memainkan } \\
\text { game lainnya }\end{array}$ & $1 / 4$ & $20 \%$ \\
\hline
\end{tabular}

Sumber: diambil dari hasil perhitungan kuisioner yang penulis berikan kepada semua karyawan dan karyawati PT. XYZ.

Tabel 10 : Aturan Asosiasi game Wanita

\begin{tabular}{|c|c|c|}
\hline Aturan & Support & Confident \\
\hline Jika & $15 / 4$ & $79,2 \%$ \\
memainkan \\
game Candy \\
Crush Saga
\end{tabular}

Yulianti, Dwi Yuni Utami, Noer Hikmah

\begin{tabular}{|c|c|c|}
\hline $\begin{array}{c}\text { maka } \\
\text { memainkan } \\
\text { game The } \\
\text { Sims }\end{array}$ & & \\
\hline $\begin{array}{c}\text { Jika } \\
\text { memainkan } \\
\text { game Candy } \\
\text { Crush Saga } \\
\text { maka } \\
\text { memainkan } \\
\text { game lainnya }\end{array}$ & $15 / 1$ & $66,7 \%$ \\
\hline
\end{tabular}

Sumber: diambil dari hasil perhitungan kuisioner yang penulis berikan kepada semua karyawan dan karyawati PT. XYZ.

Aturan Asosiasi Final Aturan asosiasi final terurut berdasarkan minimal support dan minimal confidence yang telah ditentukan, dapat dilihat pada tabel dibawah ini :

Tabel 11 : Aturan Asosiasi Final

\begin{tabular}{|c|c|c|}
\hline Aturan & Support & Confident \\
\hline $\begin{array}{c}\text { Jika memainkan } \\
\text { game Shadowrun } \\
\text { (Dragonfall), } \\
\text { maka memainkan } \\
\text { game Knight of } \\
\text { pen \& paper }\end{array}$ & $50 \%$ & $80 \%$ \\
\hline $\begin{array}{c}\text { Jika memainkan } \\
\text { game Candy } \\
\text { Crush Saga maka } \\
\text { memainkan game } \\
\text { lainnya }\end{array}$ & $50 \%$ & \\
\hline
\end{tabular}

Sumber: diambil dari hasil perhitungan kuisioner yang penulis berikan kepada semua karyawan dan karyawati PT. XYZ.

Berdasarkan aturan asosiasi diatas, dapat diketahui game apa saja yang paling banyak diminati atau dimainkan oleh karyawan dan karyawati pada PT. XYZ. Shadowrun (Dragonfall) untuk karyawan dan Candy Crush Saga untuk karyawati.

\section{KESIMPULAN}

Algoritma apriori dapat membantu dalam menentukan game apa saja yang paling banyak diminati atau dimainkan oleh orang disuatu kelompok ada disuatu database yang ada, Pengimplementasian Algoritma Apriori pada kuisioner yang telah diambil dalam PT. XYZ dan menjadikan sebuah database pada Ms. Excel, semakin banyak data kuisioner yang didapat maka semakin banyak data yang akan dibuat tabelnya. Tabel tersebut yang kemudian diolah mulai dari pembentukan nilai support dan confidence dan kemudian akan menghasilkan asosiasi final yang memenuhi nilai support dan confidentnya. Berdasarkan perhitungan dari kiusioner yang penulis 
berikan kepada semua karyawan dan karyawati PT. $\mathrm{XYZ}$ yang paling banyak dimainkan adalah game Shadowrun (Dragonfall) untuk karyawan dan Candy Crush Saga untuk karyawati.

\section{UCAPAN TERIMAKASIH}

Penulis mengucapkan banyak terimakasih kepada dosen S2 di program studi ilmu komputer dengan mata kuliah Information Retrieval System Bpk. Dr. Sfen Rianto, M.Kom yang telah membimbing dalam penulisan jurnal ini, juga kepada kedua orang tua yang selalu mendung juga kepada teman-teman kelas 14.2A.01 yang telah memberikan dukungan dalam penulisan ini

\section{REFERENSI}

Delima, R., Arianti, N. K., \& Pramudyawardani, B. (2015). Identifikasi Kebutuhan Pengguna Untuk Aplikasi Permainan Edukasi Bagi Anak Usia 4 sampai 6 Tahun. Teknik Informatika Dan Sistem Informasi, 1(April), 1-8.

Gunadi, G., \& Sensuse, D. I. (2012). Penerapan Metode Data Mining Market Basket Analysis Terhadap Penjualan Buku Dengan Menggunakan Algoritma Apriori Dan Frequent Pattern Growth ( FP-GROWTH ): Telematika Mkom, 4(1).
https://doi.org/10.1108/DLO-11-2013-0083

Mabrur, A. G., \& Lubis, R. (2012). Penerapan Data Mining Untuk Memprediksi Kriteria Nasabah Kredit. Jurnal Komputer Dan Informatika (KOMPUTA), 1(1), 53-57. https://doi.org/10.1016/j.ijom.2012.07.018

Putra, R. S., \& Utami, D. Y. (2018). Pemanfaatan Virtual Reality Pada Perancangan Game Fruit Slash Berbasis Android Menggunakan Unity 3D, $I V(2)$. https://doi.org/10.31294/jtk.v4i2.3500

Wardhani, R., \& Yaqin, M. F. (2013). Game DasarDasar Hukum Islam Dalam Kitab Mabadi ' ul Fiqh Jilid I. Game Dasar-Dasar Hukum Islam Dalam Kitab Mabadi'ul Fiqh Jilid I, 5(2), 473-478.

https://doi.org/10.1152/ajpheart.00960.2005

\section{PROFIL PENULIS}

Yulianti, S.Kom memperoleh gelar Sarjana Komputer (S.Kom) pada tahun 2018.

Dwi Yuni Utami, M.Kom memperoleh gelar Megister Komputer (M.Kom) pada tahun 2014

Noer Hikmah, M.Kom memperoleh gelar Megister Komputer (M.Kom) pada tahun 2013 